\title{
Competency in Mismatch Repair Prohibits Clonal Expansion of Cancer Cells Treated with $\mathbf{N}$-methyl-N'-nitro- $N$-nitrosoguanidine
}

\author{
John M. Carethers, ${ }^{*}$ Mary T. Hawn, ${ }^{\ddagger}$ Dharam P. Chauhan, ${ }^{\star}$ Michael C. Luce, ${ }^{\S}$ Giancarlo Marra, ${ }^{*}$ Minoru Koi, \\ and C. Richard Boland* \\ *Division of Gastroenterology, Department of Medicine, University of California, San Diego, California 92093-0688; \\ ${ }^{\ddagger}$ University of Michigan Medical School, Ann Arbor, Michigan 48109; ${ }^{\S}$ Roche Biomedical Laboratories, Research Triangle Park, \\ North Carolina 27709; and $\|$ Laboratory of Molecular Carcinogenesis, National Institutes of Environmental Health Sciences, \\ Research Triangle Park, North Carolina 27709
}

\begin{abstract}
The phenomenon of alkylation tolerance has been observed in cells that are deficient in some component of the DNA mismatch repair (MMR) system. An alkylation-induced cell cycle arrest had been reported previously in one MMR-proficient cell line, whereas a MMR-defective clone derived from this line escapes from this arrest. We examined human cancer cell lines to determine if the cell cycle arrest were dependent upon the MMR system. Growth characteristics and cell cycle analysis after MNNG treatment were ascertained in seven MMR-deficient and proficient cell lines, with and without confirmed mutations in $h M L H 1$ or $h M S H 2$ by an in vitro transcription/translation assay. MMR-proficient cells underwent growth arrest in the G2 phase of the cell cycle after the first $S$ phase, whereas MMR-deficient cells escaped an initial G2 delay and resumed a normal growth pattern. In the HCT116 line corrected for defective MMR by chromosome 3 transfer, the G2 phase arrest lasted more than five days. In another MMR-proficient colon cancer cell line, SW480, cell death occurred five days after MNNG treatment. A competent MMR system appears to be necessary for $\mathrm{G} 2$ arrest or cell death after alkylation damage, and this cell cycle checkpoint may allow the cell to repair damaged DNA, or prevent the replication of mutated DNA by prohibiting clonal expansion. (J. Clin. Invest. 1996. 98:199206.) Key words: DNA repair • cell cycle $\cdot h M L H 1 \cdot$ cell death $\cdot$ alkylation damage
\end{abstract}

The agent $N$-methyl- $N^{\prime}$-nitro- $N$-nitrosoguanidine $(\mathrm{MNNG})^{1}$ is an alkylator of DNA capable of producing the methylated pu-

\footnotetext{
Address correspondence to C. Richard Boland, Division of Gastroenterology, Department of Medicine, University of California, San Diego, 9500 Gilman Drive, San Diego, California, 92093-0688. Phone: 619-822-0304; FAX: 619-822-0301; E-mail:crboland@ucsd.edu Received for publication 14 December 1995 and accepted in revised form 18 April 1996.
}

1. Abbreviations used in this paper: $\mathrm{BrdU}, 5$-bromo-2'-deoxyuridine; DMSO, dimethylsulfoxide; IMDM, Iscove's modified Dulbecco's medium; MGMT, $\mathrm{O}^{6}$-methylguanine-DNA methyltransferase; $\mathrm{LOH}$, loss of heterozygosity; MIN, microsatellite instability; MMR, mismatch repair; MNNG, $N$-methyl- $N^{\prime}$-nitro- $N$-nitrosoguanidine; $\mathrm{O}^{6}$ $\mathrm{meG}, \mathrm{O}^{6}$-methylguanine; $\mathrm{PCR}$, polymerase chain reaction; SSCP, single-stranded conformational polymorphism.

J. Clin. Invest.

(C) The American Society for Clinical Investigation, Inc.

0021-9738/96/07/199/08 \$2.00

Volume 98, Number 1, July 1996, 199-206 rines 7-methylguanine (7-meG), 3-methyladenine (3-meA), and $\mathrm{O}^{6}$-methylguanine $\left(\mathrm{O}^{6}-\mathrm{meG}\right)$, among other adducts (1). The N-alkyl adducts (7-meG and 3-meA) are excised and repaired in cells by DNA glycosylases specific to their native nucleotide base (1), whereas $\mathrm{O}^{6}-\mathrm{meG}$ is converted to guanine by the suicide enzyme $\mathrm{O}^{6}$-methylguanine-DNA methyltransferase (MGMT) (2-4). Methylation of the $\mathrm{O}^{6}$ position on guanine is considered the initiating event in carcinogenesis by methylating agents because of its ability to produce miscoding during DNA replication, and the fact that other adducts formed by alkylating agents correlate poorly with carcinogenesis (5).

The phenotype of MNNG resistance in cultured cells can be attributed in part to adequate expression of $\operatorname{MGMT}(4,7)$. However, some cells which lack MGMT show resistance to MNNG despite the formation of alkylated guanine nucleotides $(1,8)$, and are now known to be hypermutable because of defects in the nucleotide mismatch repair (MMR) system $(9,10)$. The MMR system is composed of at least five recently discovered genes: $h M S H 2(11,12), h M L H 1(13,14), h P M S 1$, and hPMS2 (15), and GTBP (16-18). Tolerance to MNNGinduced adducts is thought to be due to a lack of recognition of $\mathrm{O}^{6}$-meG base mispairing with $\mathrm{T}$ (or $\mathrm{C}$ ) on the newly synthesized DNA strand $(2,9)$. This base mispairing is mutagenic by causing $\mathrm{G}$ to $\mathrm{A}$ transitions $(2,10)$. Correction of $\mathrm{O}^{6}$-meG-containing base pairs has been demonstrated in Escherichia coli, when wild-type levels of mutL and mutS MMR proteins are present (19). Recently, the protein complex encoded by $h M S H 2$ and GTBP (termed hMutS $\alpha$ ) has been shown to bind to nucleotide base mismatches, and is proposed to provide a target for the initiation of MMR in humans $(16-18,20)$. The alteration of guanine bases in MMR-deficient cell lines by alkylating agents suggests that this lesion is tolerable and not intrinsically cytotoxic to these cell lines $(8,9,21)$.

Alkylation-induced cell cycle arrest following DNA synthesis has been observed in some cell lines sensitive to MNNG. The human melanoma cell line MM253c1-3D, a clone resistant to $\mathrm{MNNG}$, has escaped from the G2 arrest observed in its MNNG-sensitive parent cell line MM253c1 (22). Similarly, the human lymphoblastoid B cell line MT1, which is resistant to MNNG, hypermutable, and deficient in strand-specific mismatch repair (10), has escaped MNNG-induced G2 arrest and returned to a normal cell cycle distribution (23). MT1's parental MMR proficient cell line, TK6, has been reported to proceed through a single cell division and arrest after the second $\mathrm{S}$ phase (23), events similar to that reported with HeLa cells (24) and T5-1 lymphoblasts (25). It has been proposed that the recognition of replicated $\mathrm{O}^{6}$-meG bases occurs in the daughter cells, producing a cell cycle arrest in MNNG sensitive cell lines (2). However, others have suggested that recognition of the mispair with $\mathrm{O}^{6}$-meG is responsible for $\mathrm{G} 2$ arrest after alkylation damage (23). In humans, cell extracts repair mismatched 
bases on the DNA strand containing nicks, and suggests that human MMR system is strand specific $(26,27)$. These observations suggest that the MMR system operates after DNA synthesis to replace misincorporated or mispaired nucleotides on the newly-synthesized strand in an attempt to preserve fidelity of replicated DNA. These findings also imply that the MMR system can induce cell cycle arrest after DNA synthesis in response to alkylation damage.

To ascertain whether the MMR system is involved in triggering arrest at the $\mathrm{G} 2$ phase of the cell cycle, we studied the effects of MNNG on seven human colon carcinoma cell lines with and without competency in MMR. The colon cancer cell line HCT116 is hypermutable (28), exhibits tolerance to MNNG (29), is deficient in MMR (28-30), and is known to have homozygous mutations at the $h M L H 1$ locus (13). LoVo is a colon cancer cell line with homozygous partial deletions of the $h M S H 2$ gene (31). The ovarian cell line 2774 has an hMSH 2 mutation in one allele and loss of heterozygosity $(\mathrm{LOH})$ for the other allele, and exhibits microsatellite instability (MIN) (32). SW480 is a colon cell line proficient in nucleotide MMR and lacks mutations in any of the known MMR genes (30). Recently, our laboratory developed and characterized cell lines from HCT116 which had received a normal copy of chromosome 2 and 3 by microcell fusion (29). The transfer of chromosome 3, containing the $h M L H 1$ gene, corrected MMR deficiency and hypermutability, and restored sensitivity to MNNG (29). These results suggested that the gene product from one copy of a normal $h M L H 1$ gene was enough to restore those phenotypes. The results also established that these phenotypes are recessive traits, indicating that mutations on both alleles of mismatch repair genes are permissive of tumorigenesis. Based on this background, we hypothesized that the MMR system mediates the toxicity of MNNG. The results of this study demonstrate that the presence of intact MMR activity triggered $\mathrm{G} 2$ cell cycle arrest after the first $\mathrm{S}$ phase in HCT116+ ch3 and SW480 cells, and SW480 cells died by $5 \mathrm{~d}$ after MNNG treatment. MMR-deficient cells were able to traverse a G2 phase delay and clonally expand. These findings suggest involvement of the MMR system in mediating DNA postreplicative cell cycle arrest and cell death in response to critical levels of DNA damage.

\section{Materials and Methods}

Reagents. MNNG was obtained from Aldrich Chemical Company (Milwaukee, WI) and dissolved in dimethylsulfoxide (DMSO) at a concentration of $10 \mathrm{mM}$ and stored at $-20^{\circ} \mathrm{C}$.

Cell lines and cultures. The human colon cancer cell lines HCT116, SW480, and LoVo were obtained from American Type Culture Collection (Rockville, MD) and maintained in Iscove's modified Dulbecco's medium (IMDM; GIBCO BRL, Gaithersburg, MD) containing $10 \%$ FBS. The human ovarian tumor cell line, 2774, was kindly provided by Kim Orth, Ph.D. (University of Michigan, Ann Arbor, MI) and maintained in IMDM containing 10\% FBS. HCT116 clones that had undergone human chromosome 3 transfer $(\mathrm{HCT} 116+\operatorname{ch} 3)$ and human chromosome 2 transfer (HCT116+ch2) were developed as previously described (29) and maintained in IMDM containing $10 \%$ FBS and $400 \mu \mathrm{g} / \mathrm{ml}$ of G418 (GIBCO BRL). A subclone of HCT116+ch3, designated HCT116+ch3M2, was developed in the laboratory by two successive treatments of HCT116+ch3 cells with $5 \mu \mathrm{M}$ MNNG, then selected for its resistance to MNNG (33). This cell line was maintained in IMDM containing $10 \%$ FBS and $400 \mu \mathrm{g} / \mathrm{ml}$ of G418.
In vitro transcription/translation (IVTT) assay. The methods for IVTT has been previously described (34). Briefly, total cellular RNA was purified from the cell lines by guanidinium isothiocyanate-phenol chloroform extraction (35), and reverse transcribed. Amplification of the cDNA was done by PCR primers of $h M L H 1$ and $h M S H 2$, designed to amplify each gene into two overlapping segments (34). For in vitro transcription and translation, the PCR product and $10 \mu \mathrm{Ci}$ of Tran ${ }^{35}$ S-label (ICN, Costa Mesa, CA) were added to a reticulocyte lysate kit (Promega Biotec, Madison, WI) using conditions specified by the manufacturer. Upon completion, the samples were denatured and electrophoresed on a $12.5 \%$ SDS-polyacrylamide gel.

$M N N G$ treatment. For the cell viability assay, exponentially growing cells were trypsinized and washed twice in serum-free RPMI 1640 medium. Washed cells $\left(5 \times 10^{6}\right)$ were suspended in $10 \mathrm{ml}$ of serum-free RPMI 1640 and treated with $0,2.5$, or $5 \mu \mathrm{M}$ MNNG for 45 $\min$ at $37^{\circ} \mathrm{C}$. After treatment, the cells were washed once with $10 \%$ serum-containing medium, resuspended in fresh growth medium, and seeded $\left(10^{5}\right.$ cells/well) on 24-well plates (Costar Corp., Cambridge, MA). The cells were then counted daily for $5 \mathrm{~d}$ by Trypan blue exclusion with a hemocytometer. For cell cycle analysis, exponentially growing cells were seeded $\left(1 \times 10^{5}\right)$ onto $60 \times 15 \mathrm{~mm}$ plates $($ Costar Corp.) for 2 days prior to MNNG treatment. The cells were washed with serum-free RPMI 1640 medium, then $0,2.5$, or $5 \mu \mathrm{M}$ MNNG in serum-free RPMI-1640 was added for $45 \mathrm{~min}$ at $37^{\circ} \mathrm{C}$. The MNNGcontaining medium was then removed, and replaced with fresh serum-containing growth medium.

Cloning efficiency. Exponentially growing cells were trypsinized $\left(5 \times 10^{6}\right)$ and washed twice in serum-free RPMI 1640 media. Cells were then treated with various concentrations $(0,2.5$, or $5 \mu \mathrm{M})$ of MNNG at $37^{\circ} \mathrm{C}$ for $45 \mathrm{~min}$ in $10 \mathrm{ml}$ serum-free RPMI 1640. After treatment, cells were washed once with serum-free media, resuspended in fresh growth media, diluted, and plated on $60 \times 15 \mathrm{~mm}$ plates (Costar Corp.) at $10^{4}, 10^{3}$, and $10^{2}$ cells/plate. Fresh serum-containing media was exchanged every $3 \mathrm{~d}$. After $10 \mathrm{~d}$, culture plates were washed with PBS, fixed with methanol for $15 \mathrm{~min}$, and then rewashed with PBS. The cells were then stained with $3 \%$ Giemsa stain (Sigma Chemical Co., St. Louis, MO) for $15 \mathrm{~min}$, and rinsed with water. Previously viable clonal colonies of at least 50 cells were counted using the low objective $(15 \times)$ of a microscope. The relative surviving fraction for each cell line was expressed as a ratio of the plating efficiency in treated cultures to that observed in the controls.

Cell cycle analysis. Cell cycle analysis was performed by flow cytometric measurement of the DNA content of isolated nuclei from the cells. The methods used for nuclear isolation was previously described (25). Briefly, the cells were trypsinized at 12-h intervals for $2 \mathrm{~d}$ followed by 24-h intervals for $3 \mathrm{~d}$, washed twice with PBS, and centrifuged at $250 \mathrm{~g}$ for $10 \mathrm{~min}$. The cells were resuspended at a density of $1 \times 10^{6}$ cells $/ \mathrm{ml}$ in a lysis buffer containing $10 \mathrm{mM}$ Tris $\mathrm{HCl}$ (pH 7.5), $0.32 \mathrm{M}$ sucrose, $3 \mathrm{mM} \mathrm{MgCl} 2,2 \mathrm{mM} \mathrm{CaCl}_{2}$, and $0.2 \%$ (vol/ vol) Nonidet P-40 (N-P40; Sigma Chemical Co.), and incubated on ice for $10 \mathrm{~min}$. The suspension was centrifuged at 2,000 $\mathrm{g}$ for $10 \mathrm{~min}$, and resuspended in the above lysis buffer, except without N-P40, at a density of $4 \times 10^{6}$ nuclei $/ \mathrm{ml}$. The nuclei were pelleted by centrifugation at 2,000 $\mathrm{g}$ for $10 \mathrm{~min}$, and resuspended in a buffer containing $0.1 \mathrm{M}$ Tris $\mathrm{HCl}(\mathrm{pH} 7.4), 0.15 \mathrm{M} \mathrm{NaCl}, 1 \mathrm{mM} \mathrm{CaCl}, 0.5 \mathrm{mM} \mathrm{MgCl}_{2}, 0.01 \%$ N-P40, $0.1 \%$ ribonuclease A (RNase A; Sigma Chemical Co.), and 2 $\mu \mathrm{g} / \mathrm{ml}$ propidium iodide (Sigma Chemical Co.). Subsequently, nuclei were analyzed for DNA content by the Coulter Epics C Clinical flow cytometer (Coulter Corporation, Hialeah, FL), using excitation at $488 \mathrm{~nm}$ with detection at $620 \mathrm{~nm}$ for red fluorescence. Analysis of cell cycle data was made with Multicycle Software Autofit Version 2.50 (Phoenix Flow Systems, San Diego, CA).

BrdU-Hoechst flow cytometry. Determination of the number of cell cycles traversed by a cell population was performed as previously described (36). Briefly, $1 \times 10^{5}$ asynchronous cells were treated with 0 or $5 \mu \mathrm{M}$ MNNG for $45 \mathrm{~min}$ as above and incubated in IMDM media containing 10\% FCS and $100 \mu \mathrm{M}$ 5-bromo-2'-deoxyuridine (BrdU; Boehringer Mannheim, Mannheim, Germany). Cells were harvested 

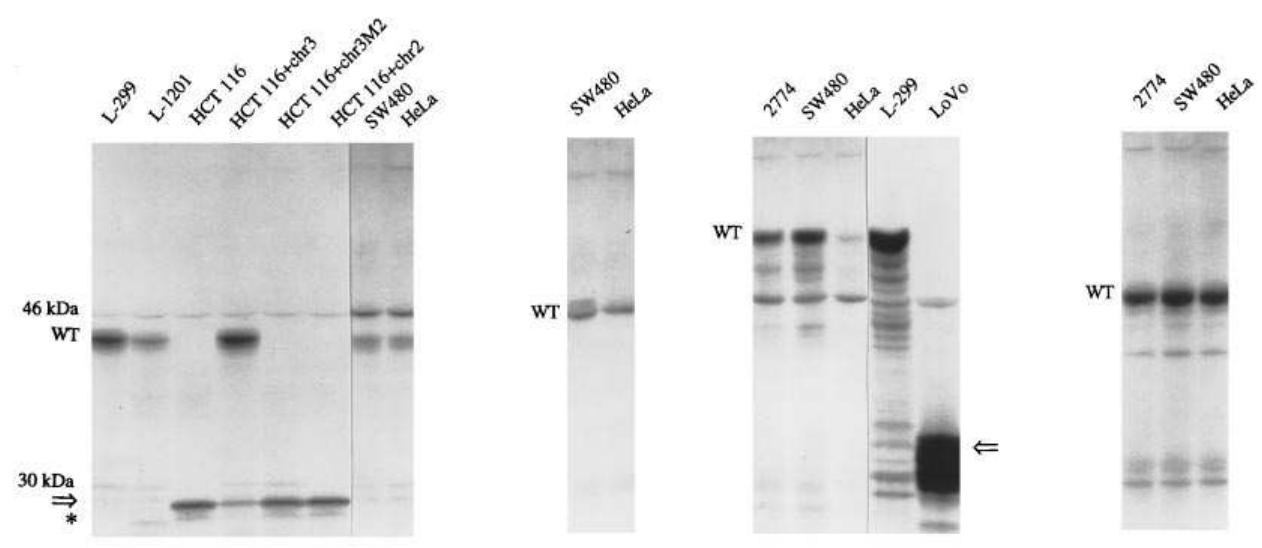

Figure 1. In vitro transcription and translation assay of the $h M L H 1$ and $h M S H 2$ proteins in seven cancer cell lines and two lymphoblast cell lines. Cells were examined for production of the $h M L H 1$ or $h M S H 2$ transcripts by reverse transcription of extracted messenger RNA, amplification of the resulting $h M L H 1$ or $h M S H 2$ cDNA by PCR into two overlapping segments, and subsequent coupled transcription and translation in an in vitro system. $(A)$ Segment 1 of the $h M L H 1$ protein. L-299 represents lymphoblasts from a patient without a truncating hMLH1 mutation, and L-1201

B

C

D

A

represents lymphoblasts from a patient with a full length segment 1 and a truncating mutation in segment 1 of $h M L H 1$ (*). The open arrow indicates the truncated $h M L H 1$ protein from HCT116 cell lines. (B) Segment 2 of the $h M L H 1$ protein. (C) Segment 1 of the $h M S H 2$ protein. The open arrow indicates truncation in LoVo cells of segment 1 of the $h M S H 2$ protein. (D) Segment 2 of the $h M S H 2$ protein. WT (wild type) represents the expected full length segment protein product.

by trypsinization at 12 -h intervals and fixed in $70 \%$ ethanol. Before flow cytometric analysis, isolated nuclei were pelleted by centrifugation at 2,000 $\mathrm{g}$, and resuspended at $4 \times 10^{5} \mathrm{cells} / \mathrm{ml}$ in a buffer containing $0.154 \mathrm{M} \mathrm{NaCl}, 0.1 \mathrm{M}$ Tris ( $\mathrm{pH} 7.4), 1 \mathrm{mM} \mathrm{CaCl}_{2}, 0.5 \mathrm{mM}$ $\mathrm{MgCl}_{2}, 0.2 \%$ bovine serum albumin, $0.1 \% \mathrm{~N}-\mathrm{P} 40,1.2 \mu \mathrm{g} / \mathrm{ml} 33258$ Hoechst (Sigma Chemical Co.), and $2 \mu \mathrm{g} / \mathrm{ml}$ propidium iodide. Cell cycle data was obtained using a Becton-Dickinson FACStar Plus flow cytometer (San Jose, CA) using UV excitation of $365 \mathrm{~nm}$ and detection of fluorescence at $460 \mathrm{~nm}$ for 33258 Hoechst, and using an excitation wavelength of $488 \mathrm{~nm}$ and detection at $630 \mathrm{~nm}$ for propidium iodide.

\section{Results}

MMR-deficient cell lines produce a truncated MMR gene transcript. We used an in vitro transcription/translation (IVTT) assay (34) to assess whether full length or truncated $h M L H 1$ or $h M S H 2$ proteins were produced by each cell line. HCT116 cells and HCT116+ch2 cells produced only a truncated $h M L H 1$ segment 1 protein, whereas HCT116+ch3, which also contains one normal, transferred $h M L H 1$ gene, produced a truncated and full length $h M L H 1$ protein (Fig. 1). The clone HCT116+ch3M2 was selected for its resistance to MNNG. This revertant cell line failed to produce the full length protein of the HCT116+ch 3 cells and only made a truncated protein of the same size as did HCT116 cells. LoVo cells produced a truncated $h M S H 2$ segment 1 protein, consistent with homozygous deletion of exons 4 to 8 of the gene (31). SW480 cells produced full length $h M L H 1$ and $h M S H 2$ proteins in both segments. The cell line 2774 produced a full length $h M S H 2$ segment, which was consistent with the reported missense mutation at codon 524 coupled with LOH of the normal $h M S H 2$ allele (32). The finding of $h M L H 1$ and $h M S H 2$ mutations by the IVTT assay accurately corresponded to the MIN phenotype in these cells, and are indicative of MMR-deficiency in cells with truncating mutations.

$M M R$-proficient cells fail to clonally expand after $M N N G$ treatment. To test the hypothesis that the MMR system is required for MNNG-induced cytotoxicity, we examined MNNG- treated human cancer cells with and without proficiency in MMR. The ability of the cancer cells to form colonies after MNNG treatment was evaluated. HCT116 + ch 3 cells exhibited a 135-fold reduction in clonal surviving fraction with $5 \mu \mathrm{M}$ MNNG compared with HCT116 cells, indicating restored sensitivity to the effects of this alkylating agent (Fig. 2). This reduction in colony formation was not seen within HCT116+ch2 and HCT116+ ch3M2 cells. LoVo and 2774 cells, both mutated in the $h M S H 2$ gene $(32,37)$, exhibited similar relative clonal efficiencies as did HCT116 cells. The relative cloning efficiency of SW480 cells, a cell line proficient in MMR (30),

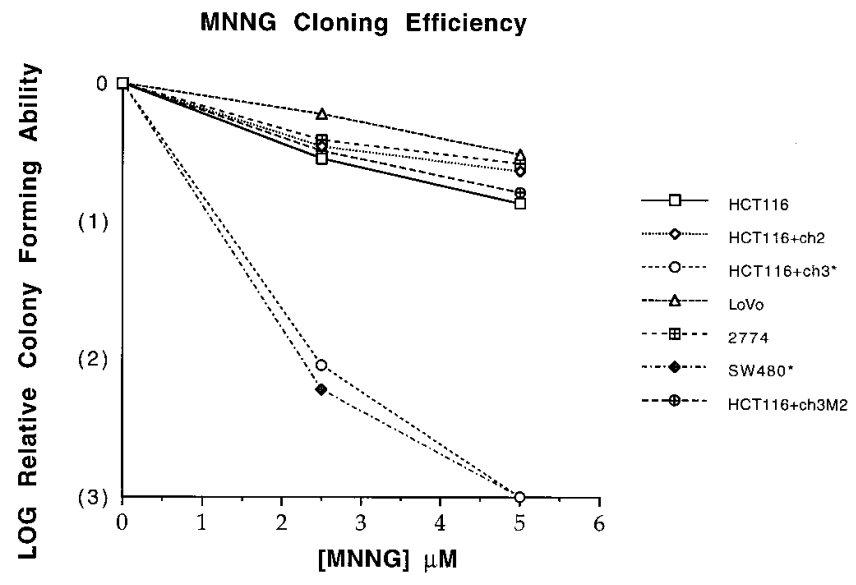

Figure 2. Colony forming ability of MMR deficient and proficient cell lines in response to MNNG. Cells were treated with $0,2.5$, or 5 $\mu \mathrm{M}$ MNNG for $45 \mathrm{~min}$ at $37^{\circ} \mathrm{C}$, plated for colony-forming ability, and then stained and fixed $10 \mathrm{~d}$ after treatment. The mean number of colonies obtained for untreated cells were (plating factor of $10^{3}$ ): HCT116, 385; HCT116+ch2, 380; HCT116+ch3, 405; HCT116+ch3M2, 245; LoVo, 194; SW480, 415; 2774, 375. Each point represents the mean of at least two independent experiments. The asterisk (*) represents MMR-proficient cell lines. 

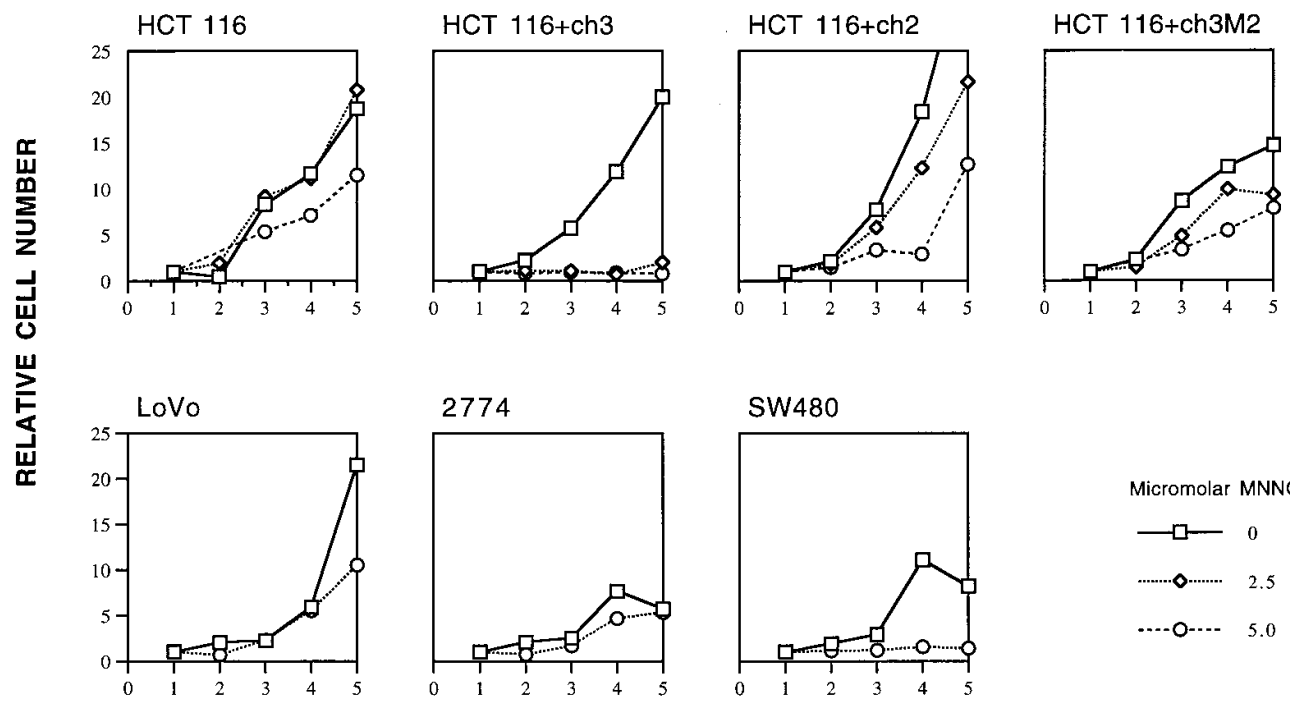

Figure 3. Growth curves of cell lines with and without treatment with MNNG. Cells were treated with 2.5 or $5 \mu \mathrm{M}$ MNNG for $45 \mathrm{~min}$ at $37^{\circ} \mathrm{C}$, plated, and then counted at 24-h intervals for $5 \mathrm{~d}$. Similar results were obtained in two independent experiments.

treated with $5 \mu \mathrm{M}$ MNNG was similar to HCT116+ch3 cells and showed sensitivity to MNNG.

Next, the effect of MNNG on cell growth was determined. Treatment of HCT116, HCT116+ch2, and HCT116+ch3M2 cells with MNNG exhibited a dosage-dependent inhibitory effect on cell growth (Fig. 3). Both 2774 and LoVo cell lines continued to increase in cell number after exposure to $5 \mu \mathrm{M} \mathrm{MNNG}$, without evidence of growth arrest. However, HCT116+ch3 and SW480 cells exposed to the same concentration of MNNG experienced growth arrest, with no increase in cell number over $5 \mathrm{~d}$. Light microscopic findings of HCT116+ch3 and SW480 cells showed the development of a flattened morphology by three days after treatment with $5 \mu \mathrm{M}$ MNNG. With further cultivation to $12 \mathrm{~d}$, treated HCT116+ch3 cells became larger and vacuolated but remained attached to the culture plate (data not shown). This appearance suggested an arrest of the DNA replicative cycle, but with ongoing cytoplasmic metabolism. Despite dosage-dependent growth inhibition, HCT116, HCT116+ ch2, and HCT116+ ch3M2 cells did not exhibit similar physical characteristics to HCT116+ch3 cells, and appeared like their untreated counterparts. Morphologically at $120 \mathrm{~h}$, treated SW480 cells had become detached from the culture plate and floated in the media.

MMR-proficient cells show DNA postreplicative cell cycle arrest or cell death after $M N N G$ treatment. We then evaluated the activity of the cell cycle after treatment with MNNG. After an initial transient $S$ phase delay within the first $12 \mathrm{~h}$, HCT116, HCT116+ch2, HCT116+ch3, HCT116+ch3M2, SW480, and 2774 cells accumulated in the G2 phase of the cell cycle by $24 \mathrm{~h}$ after treatment with $5 \mu \mathrm{M}$ MNNG (Fig. $4, A-C$ ). A lesser effect on G2 accumulation was seen in HCT116, HCT116+ch2, and $\mathrm{HCT} 116+\operatorname{ch} 3 \mathrm{M} 2$ cells treated with $2.5 \mu \mathrm{M}$ MNNG, whereas this dose yielded similar results as $5 \mu \mathrm{M}$ in HCT116+ch3 cells (data not shown). LoVo cells did not show any accumulation in $\mathrm{G} 2$ in response to $5 \mu \mathrm{M}$ MNNG, with both untreated and treated samples having $11 \%$ of cells in the G2 fraction at $24 \mathrm{~h}$. By $48 \mathrm{~h}$ after MNNG treatment, HCT116, HCT116+ch2, HCT116+ch3M2, and 2774 cells had traversed the G2 phase and entered a normal cell cycle pattern. HCT116+ch3 cells treated with 2.5 or $5 \mu \mathrm{M}$ MNNG, on the other hand, arrested in the G2 phase which persisted for more than $5 \mathrm{~d}$. This observation indicated that HCT116+ch3 cells, which possessed corrected MMR activity, exhibited a DNA postreplicative cell cycle arrest in response to MNNG. Treatment with the caffeine two days after MNNG treatment allowed HCT116+ch3 cells to enter mitosis early, which was characterized by premature chromosome condensation and fragmentation (data not shown). HCT116 and HCT116+ch2 cells, which lack a normal $h M L H 1$ gene and are defective in MMR activity, escaped G2 arrest after MNNG treatment. 2774 cells, which lack a normal $h M S H 2$ gene and exhibit MIN, also escaped G2 arrest after MNNG treatment. Cell cycle analysis of SW480 cells revealed successive accumulation of cells in the G2 phase by $48 \mathrm{~h}$ after $5 \mu \mathrm{M}$ MNNG with arrest of a large portion of cells in G2 persisting through $96 \mathrm{~h}$. However, by $120 \mathrm{~h}$, SW480 cells began to die, as they left the G2 fraction and entered a sub-G1 fraction (Fig. 4, $B$ and $C$ ). Isolation of DNA from SW480 cells at 24-h intervals for $5 \mathrm{~d}$ failed to show ladder-like fragmentation on agarose gel electrophoresis (data not shown). These observations suggested an activation of cell death after accumulation of cells in the $\mathrm{G} 2$ phase, perhaps by a mechanism different from classical apoptosis.

In addition, the clone HCT116+ch3M2, which was selected for its resistance to MNNG, behaved like parental HCT116 cells. This revertant cell line failed to produce the full length $h M L H 1$ protein seen in HCT116+ch3 cells (Fig. 1). The cell line continued to grow in the G418 selection media, indicating that disruption or loss of all of the transferred $h M L H 1$ gene had occurred during the revertant selection process while the antibiotic resistance gene had been maintained.

$M M R$-proficient cells arrest in G2/M after the first $S$ phase. Incorporation of $\mathrm{BrdU}$ was used to determine whether MNNG-treated, MMR-proficient cells arrested after the first or second $\mathrm{S}$ phase of the cell cycle. Asynchronous cells were incubated with media containing BrdU, which when incorporated into DNA, quenches Hoechst 33258 fluorescence and al- 
A

$F$
$R$
$E$
$Q$
$\mathbf{U}$
$\mathbf{E}$
$\mathbf{N}$
$\mathbf{C}$
$\mathbf{Y}$

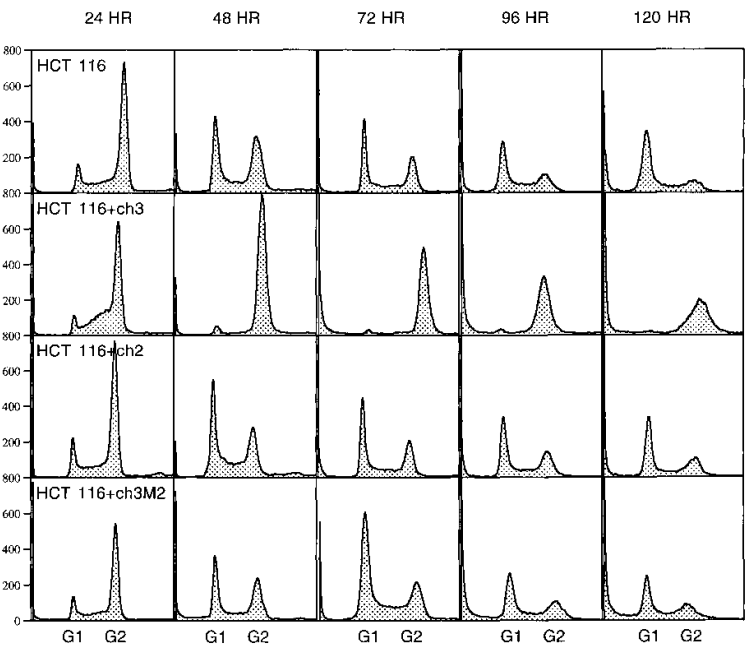

DNA Content

B

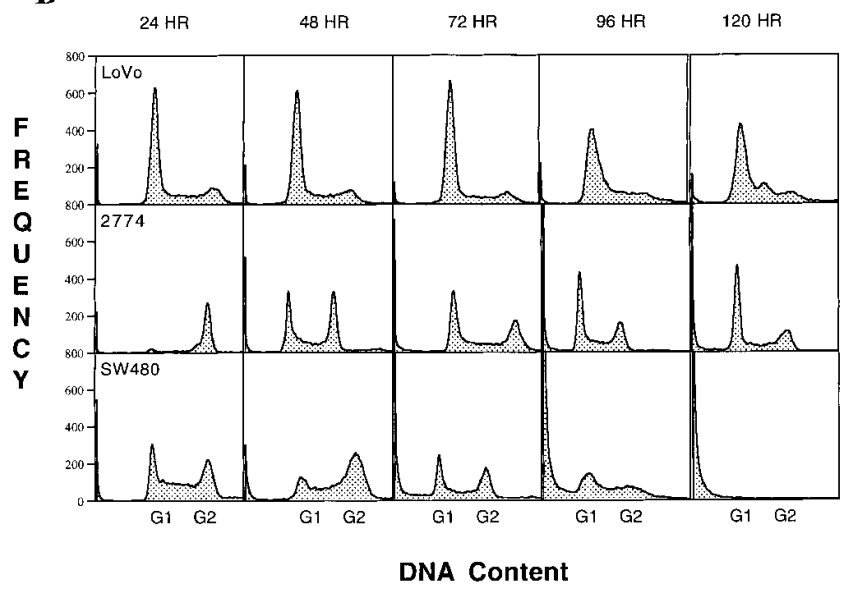

C
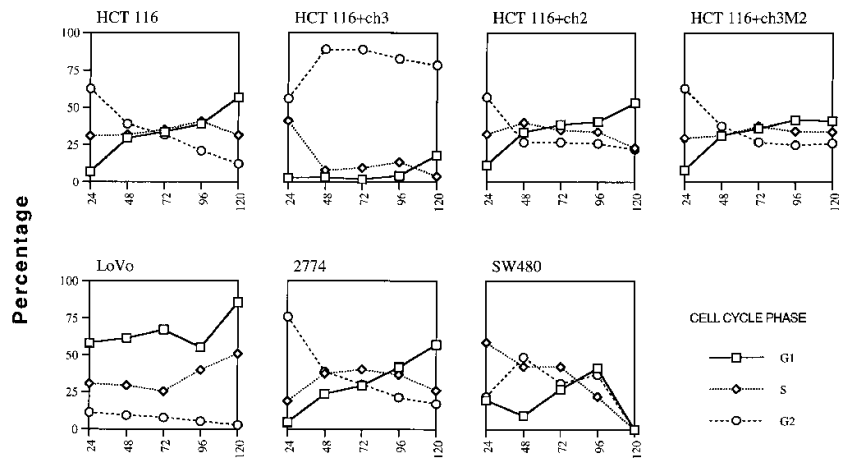

CELL CYCLE PHASE

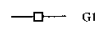

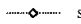

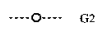

Hours

Figure 4. Representative histograms $(A$ and $B)$ and phase analysis $(C)$ of the cell cycle of MNNG-treated cell lines at 24-h intervals. Cells were treated with $5 \mu \mathrm{M} \mathrm{MNNG}$ for $45 \mathrm{~min}$ at $37^{\circ} \mathrm{C}$, plated, and then harvested at daily intervals and analyzed for their DNA content. $(A)$ HCT116, HCT116+ch3, HCT116+ ch2, and HCT116+ ch3M2 cells and $(B)$ LoVo, 2774, and SW480 cells. Similar results were obtained in eight independent experiments. $(C)$ Phase analysis of the cell cycle of MNNG-treated cell lines. Analysis was made from the histograms obtained from flow cytometry, and analyzed by Multicycle Software Autofit Version 2.50 (Phoenix Flow Systems, San Diego, CA). Each point represents the mean of at least two independent experiments. lows determination of the number of cell cycles, or the number of $\mathrm{S}$ phases passed after MNNG treatment. In combination with propidium iodide staining, each specific phase of the cell cycle can be discerned. Flow analysis indicated failure of HCT116+ch3 cells to enter the subsequent G1 phase after treatment with $5 \mu \mathrm{M} \mathrm{MNNG}$ by $48 \mathrm{~h}$ (Fig. 5), and this failure persisted through $120 \mathrm{hrs}$ (data not shown). In untreated HCT116+ch3 cells, a subsequent G1 cell cycle phase was evident by $36 \mathrm{~h}$. Therefore, HCT116+ch3 cells treated with MNNG arrested after the first S phase and did not complete mitosis. SW480 cells treated with MNNG, like HCT116+ch3 cells, also failed to enter a subsequent G1 phase, indicative of G2/M cell cycle arrest. However, SW480 cells left the G2 population by $120 \mathrm{~h}$ and entered a sub G1 population, suggestive of cell death.

\section{Discussion}

MMR-defective cell lines, including Chinese hamster ovary $\mathrm{MT}^{+}$clone B, Raji F12, MT1, SW48, and HCT116 cells exhibit a high level of tolerance to the cytotoxic action of DNA-alkylating agents $(7,9,23,29)$. It has been suggested that cell death promoted by DNA-alkylating agents may be an active process, and that the MMR system may be a general sensor for DNA damage (10). Inactivation of MMR may permit cells to escape growth arrest and cell death even in the presence of DNA alkylation. Our findings provide a mechanism to explain postreplicative cell cycle arrest and cell death in response to DNA damage.

After treatment with MNNG, cell lines deficient in some component of the MMR system (i.e., $h M L H 1$ and $h M S H 2$ ) escaped the $\mathrm{G} 2$ cell cycle arrest observed in MMR-proficient cell lines. This includes the clone HCT116+ch3M2, which had lost the full length transcript of $h M L H 1$ during revertant selection. The loss of the $h M L H 1$ transcript is the result of disruption of the $h M L H 1$ gene, as previously shown by SSCP-PCR in this cell line (33). Therefore, this phenotype appears to be directly related to the MMR system, and not MGMT expression, which is low in HCT116 cells (7). HCT116+ ch3 cells, which possess corrected MMR activity and are sensitive to MNNG, exhibited a viable arrest at the $\mathrm{G} 2$ checkpoint of the cell cycle unlike its parent cell line HCT116, whereas SW480 cells lost its replicative ability and exhibited a G2 arrest followed by cell death.

It remains to be determined what mechanism is responsible for the difference in outcome between HCT116+ch3 and SW480 cells. One possibility may be the degree of DNA damage suffered by SW480 cells compared to HCT116+ch3 cells. If HCT116+ch3 cells sustained a sublethal injury from MNNG, attempted repair of mispairs could be undertaken by the MMR system for a relatively prolonged period of time until complete repair was achieved. SW480 cells, on the other hand, could have surpassed a critical threshold of injury, and the cells activated a program of cell death. Another possibility might include the different dosage of MMR gene products between the two cell lines. SW480 cells are believed to carry two normal $h M L H 1$ alleles, whereas HCT116+ch3 carries only one normal allele. Still, another possibility is the effect of the abnormal $h M L H 1$ proteins in HCT116+ch3 cells which may compete for binding to normal $h P M S 2$ protein, and theoretically inhibit efficient MMR by interfering with the formation of a normal hMutL $\alpha$ complex through a "dominant negative" 
A

$\underline{12 \mathrm{hr}}$
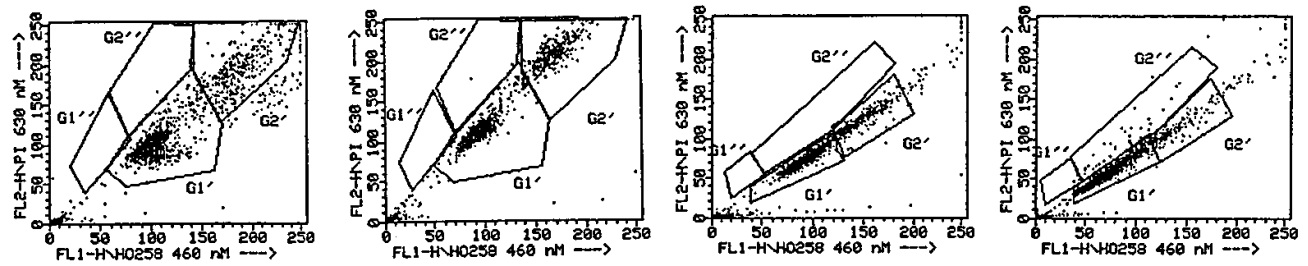

$48 \mathrm{hr}$

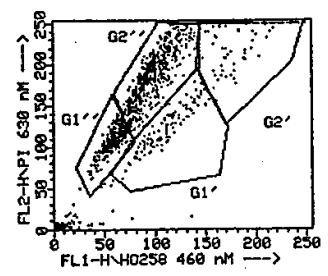

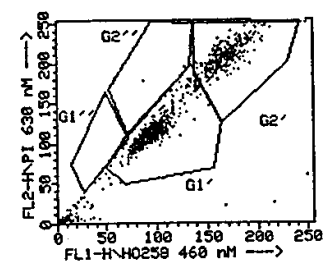

B

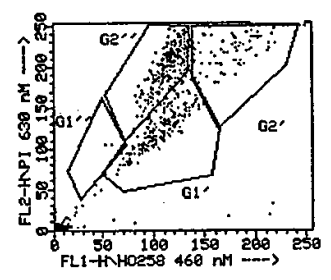

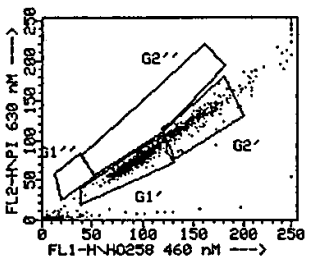

C

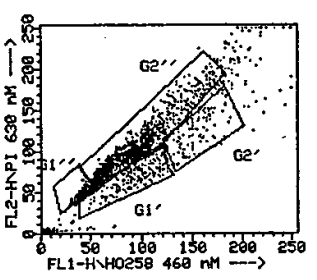

D

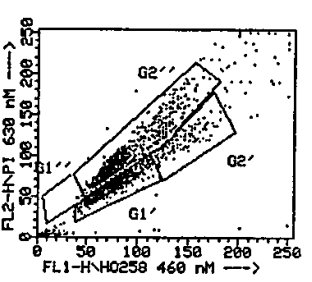

Figure 5. Representative flow scattergrams of MMR-proficient cells stained with Hoechst 33258 (x-axis) and propidium iodide (y-axis). Asynchronous cells were incubated with $100 \mu \mathrm{M}$ BrdU after treatment with 0 or $5 \mu \mathrm{M}$ MNNG, fixed in ethanol at 12-h intervals, and stained with $1.2 \mu \mathrm{g} / \mathrm{ml} 33258$ Hoechst and $2 \mu \mathrm{g} / \mathrm{ml}$ propidium iodide. When BrdU is incorporated into DNA, it quenches the Hoechst 33258 fluorescence and allows determination of the number of cell cycles passed (i.e., the number of $\mathrm{S}$ phases passed after MNNG treatment). In combination with propidium iodide staining, which indicates the DNA con-

tent of the cell, each specific phase of the cell cycle as well as the number of cell cycles can be discerned. Only the $12 \mathrm{~h}$ (upper panel) and $48 \mathrm{~h}$ (lower panel) time points are shown. (A) Untreated HCT116+ch3 cells. $(B)$ Treated HCT116+ch 3 cells. $(C)$ Untreated SW480 cells. $(D)$ Treated SW480 cells. Cells were gated by position in the cell cycle based on propidium iodide staining. HCT116+ch3 and SW480 cells treated with MNNG primarily remained in the G2" region through $120 \mathrm{~h}$ (similar to $48 \mathrm{~h}$, bottom panel), except that SW480 cells began to accumulate in a sub-G1 fraction without passing a subsequent G1 phase. Similar results were obtained in four independent experiments. G1' represents the G1 phase of the initial cell population, G2' represents the G2 phase of the initial cell population, G2" represents the first S and G2 phases (i.e., completion of one $\mathrm{S}$ phase, but before mitosis), and G1" represents a second G1 population after completion of mitosis.

mechanism (38). This may interfere with MMR, but may not permit activation of the cell death program.

The mechanism of G2 arrest after alkylation damage to DNA has been suggested by Karran et al. (2), Goldmacher et al. (23), and others (25). The DNA adduct $\mathrm{O}^{6}-\mathrm{meG}$ mimics strand-to-strand base mispairing. The MMR system recognizes the mispair and attempts to correct the mismatch prior to mitosis. Since there is no perfect complementary match for the $\mathrm{O}^{6}$-meG on the template strand, cells with competent MMR activity make a futile attempt to replace the mispair on the newly synthesized strand. Subsequent repair of the mismatch would again introduce a mispair with $\mathrm{O}^{6}-\mathrm{meG}$, causing repetitive cycles of removal and insertion of base nucleotides, which may account for prolongation and arrest of the $\mathrm{G} 2$ cell cycle phase in MMR-competent cells.

Our findings indicate that $\mathrm{G} 2$ arrest occurs after the first $\mathrm{S}$ phase, contrary to the other observations (23-25). In prior models, it was hypothesized that the alkylated base was incapable of pairing with any other natural base resulting in a gap or break in the newly synthesized DNA strand. Subsequently, cells divided normally despite the presence of the DNA break, and in the following cell cycle, this lesion (now on the template strand) caused a depression of DNA synthesis (24). The MNNG-treated MMR-competent cells in the present study did not double their number and failed to enter a subsequent G1 phase as detected by BrdU-Hoechst flow cytometry. This suggests that the MMR system can recognize the lack of a perfect complementary match for the $\mathrm{O}^{6}-\mathrm{meG}$ adduct on the template strand during the first cycle of DNA replication. Furthermore, the recognition of the mispair prevents progression of the cell cycle beyond the first G2 phase. Since repair takes place on the newly synthesized DNA strand, base mispairing with $\mathrm{O}^{6}-\mathrm{meG}$ appears to be sufficient to interfere with effective repair and signal arrest of the cell cycle.
The mechanism for the initial S and G2 phase delay after MNNG treatment observed in all of the cell lines except LoVo within the first $24 \mathrm{~h}$ is unknown. In the human MMR model, the $h M S H 2$ protein linked with the $G T B P$ protein initially binds to a newly synthesized mispair, with subsequent recruitment of the MLH homologues $(38,39)$. The binding and attempted recruitment by the hMutS $\alpha$ complex might be responsible for this delay and would explain the lack of the G2 delay in LoVo cells, which produce a truncated $h M S H 2$ transcript. However, $h M S H 2$-defective 2774 cells also had an initial delay at G2. The $h M S H 2$ mutation differs between 2774 and LoVo cell lines: 2774 cells have a missense mutation at codon 524 located in exon 10 of the $h M S H 2$ gene (32), whereas LoVo contains a deletion of exons 4 to 8 in both alleles of the $h M S H 2$ gene (31). It is possible that the protein sequence encoded by exons 4 to 8 of the $h M S H 2$ gene is responsible for the initial G2 delay observed in this study. This parallels findings showing that hMSH2 protein binds to mismatched loops of up to 14 nucleotides (40), and that LoVo cells are defective in loop repair whereas another $h M S H 2$ mutant with no mutations in these exons repairs mismatched loops (37). In 2774 cells, the abnormal protein could possibly participate in signaling the $\mathrm{G} 2$ delay after treatment with MNNG. Alternatively, a currently undetermined protein may be involved in the initial delay of the cell cycle progression.

Our results suggest that the MMR system is involved in promoting G2 cell cycle arrest and cell death after treatment with MNNG in cells that are proficient in MMR. G2 arrest was also noted in HCT116+ch3 cells that incorporated the purine analog 6-thioguanine (33). However, 6-thioguanine treated MMR-deficient cells lacked the initial S and G2 phase delay noted with MNNG-treated cells, but instead showed increase in the G1 fraction of all cell lines tested. Arrest at the G2 cell cycle checkpoint may permit the cell to attempt repair of DNA 


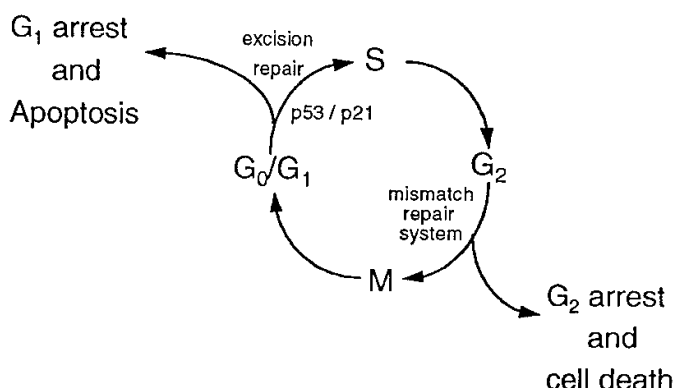

Figure 6. Model of DNA repair mechanisms and their cellular checkpoints. The MMR system appears to be involved in regulation at the G2/M checkpoint.

mismatches and prevent the replication of mutated DNA, conceptually similar to arrest at the G1/S checkpoint by p53 and p21 genes in response to DNA damage (Fig. 6). The signal generated by the alkylation damage and the MMR system to arrest the cell cycle is unknown. The cellular mechanism that regulates G2 arrest might occur through the "mitosis promoting factor" (cdc2-cyclin B complex) (41). We observed an escape from G2 arrest in MNNG-treated HCT116+ch3 cells by treatment with the methylxanthine, caffeine. It has been shown that caffeine may affect the cdc2-cyclin B complex, causing premature mitosis (42). Other agents such as nitrogen mustard prevent the dephosphorylation and activation of cdc2, causing G2 arrest and preventing mitosis (43). A similar outcome may be mediated by DNA damage caused by MNNG and recognized by the MMR system. It will be important to know if MMR proteins in some fashion regulate the cdc2cyclin B complex, or one of the complex's regulatory phosphatases or kinases to mediate cell cycle arrest. Lack of a competent MMR system might provide a key mechanism for uncontrolled cell growth as well as the hypermutable state that occurs in the absence of normal cellular checkpoints.

\section{Acknowledgments}

We kindly thank Kim Orth for providing the 2774 ovarian cancer cells.

This work was supported by National Institutes of Health grants K08 DK02433, R01 CA39233, and R25 CA57716, the Johnson Family Fund, and the Charlotte Geyer Foundation.

\section{References}

1. Aquilina, G., G. Frosina, A. Zijno, A. Di Muccio, E. Dogliotti, A. Abbondandolo, and M. Bignami. 1988. Isolation of clones displaying enhanced resistance to methylation agents in $\mathrm{O}^{6}$-methylguanine-DNA-methyltransferaseproficient CHO cells. Carcinogenesis. 9:1217-1222.

2. Karran, P., and M. Bignami. 1992. Self-destruction and tolerance in resistance of mammalian cells to alkylation damage. Nucleic Acids Res. 20:29332940.

3. Lefebvre, P., and F. Laval. 1993. A human cell line proficient in $\mathrm{O}^{6}$-methylguanine-DNA-methyltransferase and hypersensitive to alkylating agents. Carcinogenesis. 14:1671-1675.

4. Wu, Z., C.-L. Chan, A. Eastman, and E. Bresnick. 1992. Expression of human $\mathrm{O}^{6}$-methylguanine-DNA methyltransferase in a DNA excision repairdeficient Chinese Hamster Ovary cell line and its response to certain alkylating agents. Cancer Res. 52:32-35.

5. Pegg, A.E. 1984. Methylation of the $\mathrm{O}^{6}$ position of guanine in DNA is the most likely initiating event in carcinogenesis by methylating agents. Cancer Invest. 2:223-231.

6. Ishizaki, K., T. Tsujimura, H. Yawata, C. Fujio, Y. Nakabeppu, M. Sekiguchi, and M. Ikenaga. 1986. Transfer of the Escherichia coli $\mathrm{O}^{6}$-methylguanine methyltransferase gene into repair-deficient human cells and restora- tion of cellular resistance to $N$-methyl- $N^{\prime}$-nitro- $N$-nitrosoguanidine. Mutat. Res. 166:135-141.

7. Branch, P., R. Hampson, and P. Karran. 1995. DNA mismatch binding defects, DNA damage tolerance, and mutator phenotypes in human colorectal carcinoma cell lines. Cancer Res. 55:2304-2309.

8. Aquilina, G., A.M. Giammarioli, A. Zijno, A. Di Muccio, E. Dogliotti, and M. Bignami. 1990. Tolerance to $\mathrm{O}^{6}$-methylguanine and 6-thioguanine cytotoxic effects: a cross-resistant phenotype in N-methylnitrosurea-resistant Chinese hamster ovary cells. Cancer Res. 50:4248-4253.

9. Branch, P., G. Aquilina, M. Bignami, and P. Karran. 1993. Defective mismatch binding and a mutator phenotype in cells tolerant to DNA damage. $\mathrm{Na}$ ture (Lond.). 362:652-654.

10. Kat, A., W.G. Thilly, W.-H. Fang, M.J. Longley, G.-M. Li, and P. Modrich. 1993. An alkylation-tolerant, mutator human cell line is deficient in strand-specific mismatch repair. Proc. Natl. Acad. Sci. USA. 90:6424-6428.

11. Leach, F.S., N.C. Nicolaides, N. Papadopoulos, B. Liu, J. Jen, R. Parsons, P. Peltomaki, P. Sistonen, L.A. Aaltonen, M. Nystrom-Lahti, et al. 1993. Mutations of a mutS homolog in hereditary nonpolyposis colorectal cancer. Cell. 75:1215-1225.

12. Fishel, R., M.K. Lescoe, M.R.S. Rao, N.G. Copeland, N.A. Jenkins, J. Garber, M. Kane, and R. Kolodner. 1993. The human mutator gene homolog $\mathrm{MSH} 2$ and its association with hereditary nonpolyposis colon cancer. Cell. 75: 1027-1038.

13. Papadopoulos, N., N.C. Nicolaides, Y.-F. Wei, S.M. Ruben, K.C. Carter, C.A. Rosen, W.A. Haseltine, R.D. Fleischmann, C.M. Fraser, M.D. Adams, J.C. Venter, S.R. Hamilton, G.M. Petersen, P. Watson, H.T. Lynch, P. Peltomaki, J.-P. Mecklin, A. de la Chapelle, K.W. Kinzler, and B. Volgelstein. 1994. Mutation of a mutL homolog in hereditary colon cancer. Science (Wash. DC). 263:1625-1629.

14. Bronner, C.E., S.M. Baker, P.T. Morrison, G. Warren, L.G. Smith, M.K Lescoe, M. Kane, C. Earabino, J. Lipford, A. Lindblom, P. Tannergard, R.J. Bollag, A.R. Godwin, D. Ward, M. Nordenskjold, R. Fishel, R. Kolodner, and R.M. Liskay. 1994. Mutation in the DNA mismatch repair homologue $h M L H 1$ is associated with hereditary non-polyposis colon cancer. Nature (Lond.). 368 : 258-261.

15. Nicolaides, N.C., N. Papadopoulos, B. Liu, Y.-F. Wei, K.C. Carter, S.M. Ruben, C.A. Rosen, W.A. Haseltine, R.D. Fleischmann, C.M. Fraser, M.D. Adams, J.C. Venter, M.G. Dunlop, S.R. Hamilton, G.M. Peteresen, A. de la Chapelle, B. Vogelstein, and K.W. Kinzler. 1994. Mutations of two PMS homologues in hereditary nonpolyposis colon cancer. Nature (Lond.). 371:75-80.

16. Palombo, F., P. Gallinari, I. Iaccarino, T. Lettieri, M. Hughes, A. D'Arrigo, O. Truong, J.J. Hsuan, and J. Jiricny. 1995. GTBP, a 60-kilodalton protein essential for mismatch-binding activity in human cells. Science (Wash. DC). 268: 1912-1914.

17. Drummond, J.T., G.-M. Li, M.J. Longley, and P. Modrich. 1995. Isolation of an $h M S H 2$-p160 heterodimer that restores DNA mismatch repair to tumor cells. Science (Wash. DC). 268:1909-1912.

18. Papadopoulos, N., N.C. Nicolaides, B. Liu, R. Parsons, C. Lengauer, F. Palombo, A. D'Arrigo, S. Markowitz, J.K.V. Willson, K.W. Kinzler, J. Jiricny, and B. Vogelstein. 1995. Mutations of GTBP in genetically unstable cells. Science (Wash. DC). 268:1915-1917.

19. Karran, P. and M.G. Marinus. 1982. Mismatch correction at $\mathrm{O}^{6}$-methylguanine residues in E. coli DNA. Nature (Lond.). 296:868-869.

20. Fishel, R., A. Ewel, and M.K. Lescoe. 1994. Purified human MSH2 protein binds to DNA containing mismatched nucleotides. Cancer Res. 54:55395542 .

21. Green, M.H.L., J.E. Lowe, C. Petit-Frere, P. Karran, J. Hall, and H. Kataoka. 1989. Properties of N-methyl-N-nitrosurea-resistant, $\mathrm{Mex}^{-}$derivatives if an SV40-immortalized human fibroblast cell line. Carcinogenesis. 10: 893-898.

22. Hayward, I.P., and P.G. Parsons. 1984. Comparison of virus reactivation, DNA base damage, and cell cycle effects in autologous human melanoma cells resistant to methylating agents. Cancer Res. 44:55-58.

23. Goldmacher, V.S., R.A. Cuzick Jr., and W.G. Thilly. 1986. Isolation and partial characterization of human cell mutants differing in sensitivity to killing and mutation by methylnitrosurea and $N$-methyl- $N^{\prime}$-nitro- $N$-nitrosoguanidine. J. Biol. Chem. 261:12462-12471.

24. Plant, J.E., and J.J. Roberts. 1971. A novel mechanism for the inhibition of DNA synthesis following methylation: the effect of $N$-methyl- $N$-nitrosourea on HeLa cells. Chem. Biol. Interact. 3:337-342.

25. Black, K.A., R.D. McFarland, J.W. Grisham, and G.J. Smith. 1989. Cell cycle perturbation and cell death after exposure of a human lymphoblastoid cell strain to $N$-methyl- $N$ '-nitro- $N$-nitrosoguanidine. Am. J. Pathol. 134:53-61.

26. Holmes, J. Jr., S. Clark, P. Modrich. 1990. Strand specific mismatch correction in nuclear extracts of human and Drosophila melanogaster cell lines. Proc. Natl. Acad. Sci. USA. 87:5837-5841.

27. Thomas, D.C., J.D. Roberts, T.A. Kunkel. 1990. Heteroduplex repair in extracts of human HeLa cells. J. Biol. Chem. 266:3744-3751.

28. Parsons, R., G.-M. Li, M.J. Longley, W. Fang, N. Papadopoulos, J. Jen, A. de la Chapelle, K.W. Kinzler, B. Vogelstein, and P. Modrich. 1993. Hypermutability and mismatch repair deficiency in RER ${ }^{+}$tumor cells. Cell. 75:12271236 
29. Koi, M., A. Umar, D.P. Chauhan, S.J. Cherian, J.M. Carethers, T.A. Kunkel, and C.R. Boland. 1994. Human chromosome 3 corrects mismatch repair deficiency and microsatellite instability and reduces $N$-methyl- $N^{\prime}$-nitro- $N$ nitrosoguanidine tolerance in colon tumor cells with homozygous $h M L H 1 \mathrm{mu}-$ tation. Cancer Res. 54:4308-4312.

30. Umar, A., J.C. Boyer, D.C. Thomas, D.C. Nguyen, J.I. Risinger, J. Boyd, Y. Ionov, M. Perucho, and T.A. Kunkel. 1994. Defective mismatch repair in extracts of colorectal and endometrial cancer cell lines exhibiting microsatellite instability. J. Biol. Chem. 269:14367-14370.

31. Liu, B., N.C. Nicolaides, S. Markowitz, J.K.V. Willson, R.E. Parsons, J. Jen, N. Papadopolous, P. Peltomaki, A. de la Chapelle, S.R. Hamilton, K.W. Kinzler, and B. Vogelstein. 1995. Mismatch repair gene defects in sporadic colorectal cancers with microsatellite instability. Nature Genet. 9:48-55.

32. Orth, K., J. Hung, A. Gazdar, A. Bowcock, J.M. Mathis, and J. Sambrook. 1994. Genetic instability in human ovarian cancer cell lines. Proc. Natl. Acad. Sci. USA. 91:9495-9499.

33. Hawn, M.T., A. Umar, J.M. Carethers, G. Marra, T.A. Kunkel, C.R. Boland, and M. Koi. 1995. Evidence for a connection between the mismatch repair system and the G2 cell cycle checkpoint. Cancer Res. 55:3721-3725.

34. Luce, M.C., G. Marra, D.P. Chauhan, L. Laghi, J.M. Carethers, S.P. Cherian, M. Hawn, C.G. Binnie, L.N.W. Kam-Morgan, M.C. Cayouette, M. Koi, and C.R. Boland. 1995. In vitro transcription/translation assay for the screening of $h M L H 1$ and $h M S H 2$ mutations in familial colon cancer. Gastroenterology. 109:1368-1374.

35. Chomczynski, P., and N. Sacchi. 1987. Single-step method of RNA isola- tion by guanidium thiocyanate-phenol-chloroform extraction. Anal. Biochem. 162:156-159.

36. Ormerod, M.G., and M. Kubbies. 1992. Cell cycle analysis of asynchronous cell populations by flow cytometry using bromodeoxyuridine label and Hoechst-propidium iodide stain. Cytometry. 13:678-805.

37. Umar, A., J.C. Boyer, and T.A. Kunkel. 1994. DNA loop repair by human cell extracts. Science (Wash. DC). 266:814-816.

38. Li, G.-M., P. Modrich. 1995. Restoration of mismatch repair to nuclear extracts of H6 colorectal tumor cells by a heterodimer of human MutL homologs. Proc. Natl. Acad. Sci. USA. 92:1950-1954.

39. Prolla, T.A., Q. Pang, E. Alani, R.D. Kolodner, R.M. Liskay. MLH1, PMS2 and MSH2 interactions during the initiation of DNA mismatch repair in yeast. 1994. Science (Wash. DC). 265:1091-1093.

40. Fishel, R., A. Ewel, S. Lee, M.K. Lescoe, J. Griffith. 1994. Binding of mismatched microsatellite DNA sequences by human MSH2 protein. Science (Wash. DC). 266:1403-1405.

41. King, R.W., P.K. Jackson, and M.W. Kirschner. 1994. Mitosis in transition. Cell. 79:563-571.

42. Steinmann, K.E., G.S. Belinsky, D. Lee, and R. Schlegel. 1991. Chemically induced premature mitosis: differential response in rodent and human cells and the relationship to cyclin B synthesis and $\mathrm{p} 34^{\mathrm{cdc} 2} /$ cyclin B $^{\mathrm{B}}$ complex formation. Proc. Natl. Acad. Sci. USA. 88:6843-6847.

43. O'Connor, P.M., D.K. Ferris, I. Hoffmann, J. Jackman, G. Draetta, and K.W. Kohn. 1994. Role of cdc25C phosphatase in G2 arrest induced by nitrogen mustard. Proc. Natl. Acad. Sci. USA. 91:9480-9484. 